\title{
Histopathology, microbiology and the inflammatory process associated with Sarcoptes scabiei infection in the Iberian ibex, Capra pyrenaica
}

José Espinosa ${ }^{1 * \dagger}$, Arián Ráez-Bravo ${ }^{2 \dagger}$, Jorge R. López-Olvera², Jesús M. Pérez ${ }^{1}$ Santiago Lavín², Asta Tvarijonaviciute ${ }^{3}$, Francisco J. Cano-Manuel ${ }^{4}$, Paulino Fandos ${ }^{5}$, Ramón C. Soriguer ${ }^{6}$, José Enrique Granados ${ }^{4}$, Diego Romero ${ }^{7}$ and Roser Velarde ${ }^{2}$

\begin{abstract}
Background: Sarcoptic mange has been identified as the most significant infectious disease affecting the lberian ibex (Capra pyrenaica). Despite several studies on the effects of mange on ibex, the pathological and clinical picture derived from sarcoptic mange infestation is still poorly understood. To further knowledge of sarcoptic mange pathology, samples from ibex were evaluated from histological, microbiological and serological perspectives.

Methods: Samples of skin, non-dermal tissues and blood were collected from 54 ibex (25 experimentally infected, 15 naturally infected and 14 healthy). Skin biopsies were examined at different stages of the disease for quantitative cellular, structural and vascular changes. Sixteen different non-dermal tissues of each ibex were taken for histological study. Acetylcholinesterase and serum amyloid A protein levels were evaluated from blood samples from ibex with different lesional grade. Samples of mangy skin, suppurative lesions and internal organs were characterized microbiologically by culture. Bacterial colonies were identified by a desorption/ionization time-of-flight mass spectrometry system (MALDI TOF/TOF).

Results: The histological study of the skin lesions revealed serious acanthosis, hyperkeratosis, rete ridges, spongiotic oedema, serocellular and eosinophilic crusts, exocytosis foci, apoptotic cells and sebaceous gland hyperplasia. The cellular response in the dermis was consistent with type I and type IV hypersensitivity responses. The most prominent histological findings in non-dermal tissues were lymphoid hyperplasia, leukocytosis, congestion and the presence of amyloid deposits. The increase in serum concentrations of acetylcholinesterase and amyloid A protein correlated positively with the establishment of the inflammatory response in mangy skin and the presence of systemic amyloidosis. A wide variety of bacterial agents were isolated and the simultaneous presence of these in mangy skin, lymph nodes and internal organs such as lungs, liver, spleen and kidney was compatible with a septicaemic pattern of infection.
\end{abstract}

Conclusions: The alteration of biomarkers of inflammation and its implication in the pathogenesis of the disease and development of lesions in non-dermal tissues and septicaemic processes are serious conditioners for the survival of the mangy ibex. This severe clinical picture could be an important factor when considering the decision to eliminate animals that exceed a certain disease threshold from a population.

Keywords: Acetylcholinesterase, Bacteria, Lesion, Mangy skin, Non-dermal tissue, Sarcoptic mange, Serum amyloid a

\footnotetext{
* Correspondence: jcerrato@ujaen.es

${ }^{\dagger}$ Equal contributors

'Departamento de Biología Animal, Vegetal y Ecología, Universidad de Jaén,

Campus Las Lagunillas s/n, 23071 Jaén, Spain

Full list of author information is available at the end of the article
} 


\section{Background}

Sarcoptic mange is a highly contagious infection of the skin caused by the burrowing mite Sarcoptes scabiei that affects both humans and animals worldwide [1]. It is responsible for epizootic disease in several wild ungulate and carnivore species [2-4]. Severe outbreaks of sarcoptic mange have been reported in the Iberian ibex (Capra pyrenaica), some of which have led to high mortality rates $[5,6]$. Although many studies have addressed sarcoptidosis in Iberian ibex in recent last years, the pathogenicity of the infection in this host is still not yet fully understood.

Clinical signs of sarcoptic mange generally include a combination of alopecia, scaling and crusting [7]. However, the severity and distribution of these lesions, as well as the outcome of the disease, vary between host species and individuals of the same species [1, 8]. Mild infestations often have little effect on hosts, although chronic infestations can affect fat reserves and foodconversion efficiency $[9,10]$. Anemia, damage to inner organs and secondary bacterial complications may also compromise the survival of the host [11-13].

Despite the availability of wide-ranging information on the pathology of sarcoptic mange in the Iberian ibex [14-17], there are still few studies that address the pathological changes that occur in the skin and organs in mangy ibex. The objectives of this study were thus (i) to provide detailed histological descriptions of mangy skin at different stages of the disease; (ii) to assess histological changes in non-dermal organs in ibex with severe sarcoptic mange; (iii) to analyze the activity of markers of the inflammatory process and their implication in the pathogenesis of the disease; and (iv) to characterize microbiologically mangy skin and lesions as a means of identifying possible signs of secondary sepsis. To achieve these goals, we surveyed ibex that were both naturally and experimentally infected with S. scabiei.

\section{Methods}

\section{Experimental facilities and animals}

Thirty nine Iberian ibex (C. p. hispanica) (22 males and 17 females; $1-11$ years of age) were captured, 33 in the Sierra Nevada Natural Space (SNNS) $\left(36^{\circ} 55^{\prime}\right.$ to $37^{\circ} 10^{\prime}$ $\mathrm{N}, 2^{\circ} 56^{\prime}$ to $\left.3^{\circ} 38^{\prime} \mathrm{W}\right)$, and 6 in the Sierras de Cazorla, Segura y Las Villas Natural Park (SCSVNP) (37 $53^{\prime}$ to $37^{\circ} 88^{\prime} \mathrm{N}, 2^{\circ} 53^{\prime}$ to $\left.2^{\circ} 88^{\prime} \mathrm{W}\right)$. Initial IgG levels against $S$. scabiei were measured by an enzyme-linked immunosorbent assay (ELISA) developed for alpine chamois (Rupicapra rupicapra) in order to exclude ibex that had previously been in contact with the disease [18]. Captured ibex were transferred to experimental facilities located in southern Spain (Las Mimbres, Sierra de Huétor Natural Park, $37^{\circ} 18^{\prime}$ to $37^{\circ} 30^{\prime} \mathrm{N}, 3^{\circ} 28^{\prime}$ to $\left.3^{\circ} 47^{\prime} \mathrm{W}\right)$. They were kept in small groups (4-6 animals) in separate enclosures under observation during an eight-week acclimatization period. All ibex had ad libitum access to food and water $[19,20]$.

In addition, 15 naturally infested free-ranging ibex (nine males and six females; 4-9 years of age) were selectively harvested as part of a management program devoted to controlling both ibex density and the spread of sarcoptic mange in the SNNS.

All ibex were captured using a rifle and anaesthetic darts with a combination of ketamine $(3 \mathrm{mg} / \mathrm{kg})$ and xylazine $(3 \mathrm{mg} / \mathrm{kg})$ [21].

\section{Experimental infestation}

After an adaptation period, 25 of the 39 ibex (22 from SNNS and three from SCSVNP) were experimentally infested with S. scabiei, and the remaining 14 ibex being left to act as controls. A $2 \mathrm{~cm}^{2}$ skin fragment from a naturally S. scabiei-parasitized wild ibex from the SNNS was attached with elastic bandages to the previously shaved inter-scapular region to induce contact between the mites and the host skin. In order to determine the density and therefore the number of mites infesting each ibex, the density of mites was calculated in skin pieces adjacent to those used for the infestation. In these adjacent skin samples, mites were counted with a stereomicroscope after overnight digestion in $5 \% \mathrm{KOH}$ solutions at $40{ }^{\circ} \mathrm{C}[22]$ and a thermal gradient induced by a light shone from below Petri dishes with black bottoms and transparent central areas [23].The resulting estimated dose received by each ibex was $750 \pm 440$ mites.

The experimental period lasted for 150 days after infestation. Experimentally and naturally infected ibex were visually assigned to one of the following three categories defined according to the percentage of skin surface affected: healthy (mange-free ibex), mild (initial and development stages, with lesions on $<50 \%$ of the host skin surface), and severe (consolidation and chronic stages with lesions on more than $50 \%$ of the host skin surface) [22].

\section{Blood and skin sample collection}

Blood samples and skin biopsies were collected at 26, 46, 103 and 150 days post-infestation (dpi). Blood samples $(20 \mathrm{ml})$ were taken from each ibex (both infested and control animals) by jugular venipuncture, and kept at $4{ }^{\circ} \mathrm{C}$ in a cooling box until reaching the laboratory. Adjacent skin biopsies were taken after shaving the inter-scapular region using an $8 \mathrm{~mm}$ diameter punch biopsy tool (KRUUSE ${ }^{\ominus}$ Biopsy Punch, Langeskov, Denmark). In the control group, skin samples were only collected at $103 \mathrm{dpi}$. To do so, each ibex was separated into a handling crush for subsequent physical restraint (blindfolding and limb immobilization) and a local anaesthetic was administered (ANESVET ${ }^{\oplus}$, Ovejero Lab, 
León, Spain). After collecting the skin samples, each animal was treated with an antiseptic spray. Each biopsy was placed into $10 \%$ neutral buffered formalin for $48-$ $72 \mathrm{~h}$, and then transferred to $60 \%$ ethanol and stored at $4{ }^{\circ} \mathrm{C}$ until histological analysis.

\section{Necropsy and sample collection}

Nineteen of the 25 ibex experimentally infected were euthanized at $150 \mathrm{dpi}$ due to their severe mange infections. Naturally infected animals (all with more than $50 \%$ of their skin surface affected) were euthanized at the time of capture. Before euthanasia, blood samples were collected from each ibex. Animals were anaesthetized by intramuscular injection with a mixture of xylazine $(3 \mathrm{mg} / \mathrm{kg}$ ) and ketamine $(3 \mathrm{mg} / \mathrm{kg})$, and euthanized with T-61 ${ }^{\circ}$ (embutramide $12 \mathrm{mg} / \mathrm{kg}$, membezonium iodide $3 \mathrm{mg} / \mathrm{kg}$, tetracaine $0.3 \mathrm{mg} / \mathrm{kg}$ ).

Scabietic ibex were necropsied under strict hygienic conditions immediately after death. Gross pathologic examination was performed on all animals and organs following a standard protocol. The following samples were collected from each ibex for histological study: superficial lymph nodes (SLN) draining the mangy skin lesions (submandibular, parotid, pre-scapular, subscapular, inguinal, mammary and popliteal), intracavitary lymph nodes (ILN) (mediastinal, mesenteric, hepatic, renal), central nervous system, tongue, thyroid gland, skeletal muscle, heart (papillary muscle), lungs (apical, middle and caudal lobes), liver, kidney, adrenal gland, spleen, pancreas, small intestine (ileum), large intestine (colon), ovary and testicle. All samples were fixed in a similar way to the skin biopsies. For the microbiological studies, the following samples were taken and stored separately in sterile tubes: skin (especially lesions of exudative dermatitis and/or abscesses), suppurative lesions, lungs, liver, spleen and kidney.

\section{Histopathology}

Skin biopsies and the rest of the fixed non-dermal tissues were briefly washed with $10 \%$ phosphate buffered saline (PBS) solution and embedded in paraffin wax (EI LEICA TP1020 Automatic Tissue Processor ${ }^{\circ}$, Barcelona, Spain). Serial $5 \mu \mathrm{m}$ sections from all specimens were mounted on glass slides (Super-Frost, Menzel-Gläser, Braunschweig, Germany), stained with haematoxylin and eosin (HE) and analyzed by light microscopy.

Skin sections were examined for quantitative cellular, structural and vascular changes (Table 1). Epidermal changes were evaluated in three randomly selected complete microscopic cross-sections. The final value

Table 1 Median \pm SD of histopathological changes assessed in sarcoptic mange skin lesions on the different days post-infection

\begin{tabular}{|c|c|c|c|c|c|c|}
\hline & Healthy & $26 \mathrm{dpi}$ & $46 \mathrm{dpi}$ & 103 s dpi & 103 dpi & 150 dpi \\
\hline \multicolumn{7}{|l|}{ Epidermis } \\
\hline Mites/burrows ${ }^{1}$ & 0.00 & $1.45 \pm 0.82^{\mathrm{a}}$ & $3.18 \pm 1.25^{b}$ & $0.60 \pm 1.57^{a}$ & $3.51 \pm 6.18^{b}$ & $1.63 \pm 1.68^{\mathrm{a}}$ \\
\hline Basal cell hyperplasia/acanthosis ${ }^{2}$ & 5.00 & $15.54 \pm 2.54^{\mathrm{a}}$ & $12.77 \pm 1.8^{b}$ & $9.95 \pm 2.88^{c}$ & $13.80 \pm 3.93^{b}$ & $12.22 \pm 2.60^{b}$ \\
\hline Rete ridges ${ }^{3}$ & 0.00 & $17.08 \pm 4.81^{\mathrm{a}}$ & $13.10 \pm 4.62^{b}$ & $7.40 \pm 3.80^{c}$ & $14.40 \pm 3.23^{b}$ & $15.01 \pm 3.92^{b}$ \\
\hline Spongiotic oedema ${ }^{4}$ & 0.00 & $14.45 \pm 3.85^{\mathrm{a}}$ & $15.36 \pm 3.29^{\mathrm{a}}$ & $4.50 \pm 3.77^{c}$ & $10.50 \pm 3.83^{b}$ & $7.18 \pm 5.54^{b}$ \\
\hline Serocellular crusts ${ }^{5}$ & 0.00 & $2.90 \pm 0.54^{\mathrm{a}}$ & $3.18 \pm 0.60^{a}$ & $0.41 \pm 0.69^{b}$ & $3.20 \pm 1.13^{\mathrm{a}}$ & $0.72 \pm 0.64^{b}$ \\
\hline Eosinophilic crusts $^{6}$ & 0.00 & $2.81 \pm 0.60^{\mathrm{a}}$ & $3.27 \pm 0.78^{\mathrm{a}}$ & $0.61 \pm 0.70^{b}$ & $3.30 \pm 0.67^{a}$ & $0.90 \pm 0.83^{b}$ \\
\hline Exocytosis foci ${ }^{7}$ & 0.00 & $12.82 \pm 4.19^{a}$ & $13.81 \pm 3.91^{\mathrm{a}}$ & $3.50 \pm 3.06^{c}$ & $9.10 \pm 3.51^{b}$ & $6.10 \pm 3.76^{b}$ \\
\hline Apoptosis/necrosis ${ }^{8}$ & 0.00 & $12.27 \pm 3.06^{\mathrm{a}}$ & $14.54 \pm 2.65^{\mathrm{a}}$ & $2.90 \pm 2.88^{c}$ & $9 \pm 3.80^{b}$ & $6.08 \pm 5.85^{b}$ \\
\hline \multicolumn{7}{|l|}{ Dermis } \\
\hline Sebaceous glands & 8.00 & $27.27 \pm 3.70^{\mathrm{a}}$ & $24.54 \pm 3.32^{\mathrm{a}}$ & $19.4 \pm 6.10^{b}$ & $25.11 \pm 6.65^{\mathrm{a}}$ & $21.10 \pm 3.17^{b}$ \\
\hline Lymphocytes & 18.68 & $45.97 \pm 11.85^{\mathrm{a}}$ & $44.67 \pm 12.14^{a}$ & $29.31 \pm 6.48^{b}$ & $34.46 \pm 13.40^{b}$ & $31.81 \pm 90^{b}$ \\
\hline Eosinophils & 0.20 & $8.49 \pm 0.94^{a}$ & $11.40 \pm 1.16^{a}$ & $2.02 \pm 5.81^{b}$ & $4.23 \pm 2.64^{b}$ & $5.14 \pm 1.74^{b}$ \\
\hline Mast cells & 0.10 & $6.72 \pm 0.69^{a}$ & $8.32 \pm 0.92^{a}$ & $1.14 \pm 2.24^{b}$ & $3.42 \pm 1.14^{b}$ & $2.53 \pm 1.29^{b}$ \\
\hline Neutrophils & 0.00 & $3.52 \pm 4.48^{\mathrm{a}}$ & $4.17 \pm 1.76^{a}$ & $0.71 \pm 1.27^{c}$ & $2.41 \pm 3.39^{b}$ & $2.77 \pm 3.62^{b}$ \\
\hline Plasma cells & 0.00 & $0.53 \pm 0.24^{\mathrm{a}}$ & $0.64 \pm 0.11^{a}$ & $0.37 \pm 0.24^{\mathrm{a}}$ & $0.42 \pm 0.23^{\mathrm{a}}$ & $0.43 \pm 0.55^{a}$ \\
\hline
\end{tabular}

${ }^{1}$ Number of mites and/or burrows

${ }^{2}$ Number of cells layers from the basal lamina to the stratum granulosum

${ }^{3}$ Number of rete ridges along the basal lamina

${ }^{4}$ Number of cells with hydropic degeneration

${ }^{5}$ Areas of transudation

${ }^{6}$ Areas of intense eosinophilic infiltration associated with thepresence of mites and/or burrows

${ }^{7}$ Number of exocytosis focus of inflammatory cells associated with vasodilation and vascular neoformation

${ }^{8}$ Number of cells with hyperchromatosis with karyorrhectic and pyknotic nuclei

Notes: On day 103 post-infection the ibex that showed self limiting clinic process were included separately (included in column $103 \mathrm{~s}$ dpi). Values that have different superscript letters (a-c) along the row differ significantly 
was expressed as the average of the observations of the three sections. The counts of dermal inflammatory cell infiltrations (neutrophils, plasma cells, mast cells, eosinophils and lymphocytes) were performed in five randomly selected fields at 400x magnification in one section taken from the skin. The final number of cells was expressed as an average count at 400 $\times$ HPF (highpowered fields). For the rest of the organs, three randomly selected cross-sections from each tissue were evaluated at $200 \times$ magnification.

\section{Acetylcholinesterase (AChE) and serum amyloid a (SAA) assay}

Within $24 \mathrm{~h}$ of collection, serum was obtained by centrifugation at $4750 \times g$ for $10 \mathrm{~min}$ and stored separately at $-82{ }^{\circ} \mathrm{C}$. Serum SAA concentrations $(\mu \mathrm{g} / \mathrm{ml})$ were quantified as the mean value of two measurements using a commercially available ELISA kit (Tridelta Phase ${ }^{\mathrm{Th}}$ range serum amyloid, A Tridelta Development Ltd., Bray, Ireland). AChE activity ( $\mu \mathrm{mol} / \mathrm{ml} * \mathrm{~min})$ was measured using acetylthiocholine as a substrate [24]. The method was adapted to an automatic analyzer [25].

\section{Microbiology}

In the laboratory, samples were processed in biological safety cabinets within $12 \mathrm{~h}$ after collection. Twenty grams of each tissue and/or pathological material was placed in a sterile airtight bag with $3 \mathrm{ml}$ of sterile $10 \%$ PBS and homogenized for 5 min (Stomacher 80 Biomaster ${ }^{\circ}$, Lardero, Spain). An aliquot of $800 \mu \mathrm{l}$ of the resulting homogenate was added to a sterile cryotube together with $200 \mu \mathrm{l}$ of glycerol. The cryo tubes were stored at $-20{ }^{\circ} \mathrm{C}$ until microbiological analysis.

Samples were cultured on TSA and Columbia agar plates supplemented with $5 \%$ sheep blood (bioMérieux, Madrid, Spain) and incubated aerobically at $37{ }^{\circ} \mathrm{C}$ for 24-48 h. Cells from representative bacterial pure and freshly-cultivated colonies were re-suspended in $300 \mu \mathrm{l}$ of HPLC-grade water and mixed vigorously prior to the addition of $900 \mu \mathrm{l}$ of HPLC-grade ethanol. Subsequently, an acetonitrile/formic acid extraction protocol was performed following the manufacturer's instructions (Bruker Daltonik, Bremen, Germany). After protein extraction, $1 \mu \mathrm{l}$ of each isolate extract was spotted onto a 384-spot polished steel target plate, left to dry at room temperature and then overlaid with $1 \mu \mathrm{l}$ of $\alpha$-cyano-4hydroxy-cinnamic acid (HCCA) matrix. All isolates were analyzed in a Bruker Daltonik UltrafleXtreme MALDI TOF/TOF (desorption/ionization time-of-flight mass spectrometry) system, which obtained one spectrum per sample used to assess the suitability of this spectrometric approach for identification at species level. Each spectrum was acquired using FlexControl software (Version 3.4) in automatic mode in a random sampling pattern. The identification of all the clinical isolates in this study was performed by MALDI Biotyper Real Time Classification software. The reliability of the identification was evaluated from the $\log$ (score) values, calculated with the MALDI Biotyper software mentioned above.

\section{Data analysis}

The results of the histopathological changes and serum SAA and AChE concentrations were reported as median and standard deviations, calculated using routine descriptive statistical procedures. The Kolmogorov-Smirnov test was used to assess data normality. Non-parametric statistical methods were used to compare groups. A Mann-Whitney U-test was employed to compare the control group with the clinical stage of the exposed groups. To evaluate the response of the different parameters in term of the time of exposure and mange status of the different infested groups, Friedman tests with repeated measures were performed. In a second step, a Wilcoxon signed rank post-hoc comparison test with Bonferroni correction was used to determine the differences between the groups analyzed. A Spearman's rank correlation coefficient test was applied to establish the coefficients between the different variables analyzed. To compare the frequency of lesions observed in non-dermal tissues between experimentally exposed and naturally infected animals, the Fisher's exact test was used. $P$-values $<0.05$ were considered to be statistically significant.

All statistical analyses were performed with the R software version 3. 3. 1 ( $\mathrm{R}$ Development Core Team, December 2016) [26].

\section{Results}

\section{Clinical signs}

The clinical outcome and evolution of the infested ibex changed during the infestation period. Sixteen infested ibex progressed to severe stages of the disease. However, seven ibex, all of which from SNNS, only developed a self-limiting clinic process, with mange lesions on less than $50 \%$ of their skin surface, and showed evident signs of recovery. All infested ibex from SCSVNP evolved to severe stages of the disease. Until $46 \mathrm{dpi}$, all ibex developed localized lesions in the inoculation zone (interscapular area) and facial area (mildly affected). From 103 dpi onwards, in all ibex except those with a self-limiting clinic process, mange lesions were generalized, extending over the lumbar region and the ventral part of the abdomen and limbs (severely affected). Animals showed pruritus throughout the disease and intermittently scratched themselves. In the most severe clinical stages, both naturally and experimentally infested ibex showed scales, marked lichenification, alopecia, crusts, dermal fissures in limbs and moderate inflammation of eyelids 


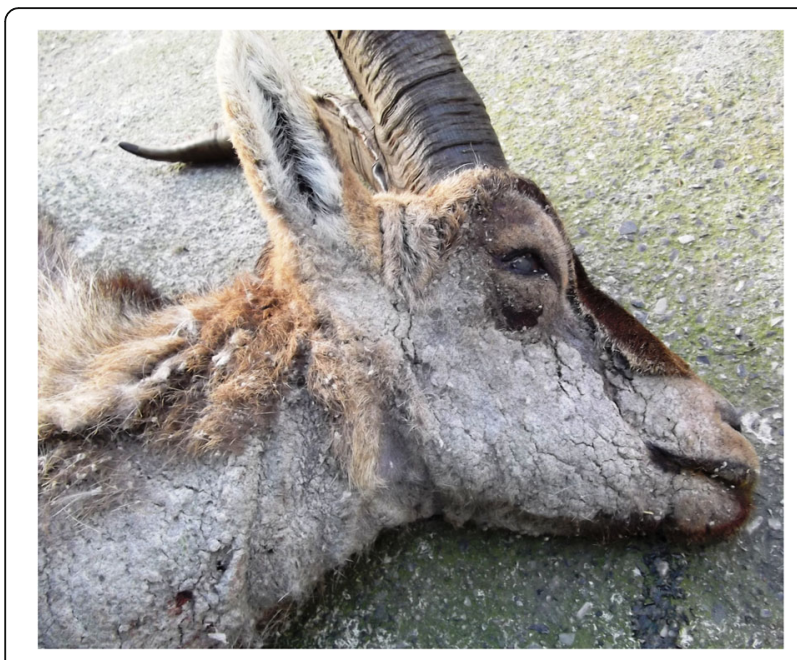

Fig. 1 Iberian ibex with severe sarcoptic mange. Presence of thick crusts, scales and alopecia in facial area and neck

and lips (Fig. 1). In the terminal phase, animals showed weakness, prostration and weight loss.

\section{Histopathological and microbiological findings}

Histopathological changes in mangy skin between dpi were compared and shown in Table 1. Such changes were detected in all of the analyzed stages, both in the ibex that progressed to more severe stages and in those with a self-limiting clinic process, and always in amounts significantly $(P<0.0001)$ higher than those of the control group (Fig. 2a). For the epidermis, the median values of mites/burrows varied between different dpi (Friedman's test: $\chi^{2}=93.94, d f=2, P=0.022$ ), increasing significantly (post-hoc test: $P=0.012$ ) between 46 and 103 dpi. In the final stage the values decreased and returned to the levels of the early stages of the disease. The number of eosinophilic and serocellular crust foci were correlated $\left(r_{(353)}=0.546, P<0.0001\right.$ and $r_{(384)}=0.402, P=0.0012$, respectively) with the presence of mites/burrows, but values were significantly (post-hoc tests: $P=0.012$ and $P=0.0093$, respectively) lower by $150 \mathrm{dpi}$. Acanthosis
(Friedman $F_{r}$ test: $\chi^{2}=98.04, d f=2, P=0.003$ ) and rete ridges (Friedman $F_{r}$ test: $\chi^{2}=98.84, d f=2, P=0.002$ ) showed variation along the different $d p i$. These reached their maximum number (post-hoc tests: $P=0.032$ and $P=0.044$, respectively) by $26 \mathrm{dpi}$ and then decreased significantly (post-hoc tests: $P=0.012$ and $P=0.022$, respectively) by $46 \mathrm{dpi}$, remaining unchanged during the rest of the disease. Likewise, acanthosis was correlated $\left(r_{(394)}=0.329, P=0.031\right)$ with the presence of mites/burrows. Signs of cytotoxicity such as spongitic oedema, apoptotic keratinocytes and exocytosis foci increased significantly (post-hoc test: $P<0.0001$ ) up to $46 \mathrm{dpi}$ (Fig. 2b), and then decreased significantly (post-hoc test: $P<0.0001)$ during the more severe stages (from 103 dpi onward) (Fig. 2c). In ibex with self-limiting lesions, all epidermal changes were significantly (post-hoc test: $P<0.0001$ ) lower than those that progressed to severe stages (103and $150 \mathrm{dpi}$ ), and were even lower than those observed during the first days of the disease (26 dpi).

In the dermis, the number of sebaceous glands also varied according to dpi (Friedman $F_{r}$ test: $\chi^{2}=90.14, d f$ $=2, P=0.036$ ), remaining unchanged until $150 \mathrm{dpi}$, at which point their number fell significantly (post-hoc test: $P=0.044)$. The number of lymphocytes $\left(r_{(343)}=0.586\right.$, $\left.r_{(346)}=0.584, \quad r_{(286)}=0.640\right)$, eosinophils $\quad\left(r_{(431)}=0.284\right.$, $\left.r_{(398)}=0.324, \quad r_{(452)}=0.205\right)$, mast cells $\quad\left(r_{(277)}=0.763\right.$, $\left.r_{(281)}=0.699, \quad r_{(149)}=0.811\right)$ and neutrophils $\left(r_{(293)}=\right.$ $\left.0.699, r_{(354)}=0.566, r_{(366)}=0.515\right)$ was significantly correlated $(P<0.0001)$ with the presence of spongiotic oedema, exocytosis foci and apoptotic cells respectively. With the exception of plasma cells (Friedman $F_{r}$ test: $\left.X^{2}=10.96, d f=2, P=0.067\right)$, the number of lymphocytes, mast cells, eosinophils and neutrophils was significantly ( $P=0.0023, P=0.012, P=0.0087, P=0.0023$, respectively) higher during the first $46 \mathrm{dpi}$, but then decreased significantly $(P<0.001)$. The number of plasma cells was low in all the stages analyzed. In animals with self-limiting lesions, the number of inflammatory cells decreased significantly (post-hoc test: $P<0.0001$ ) in relation to the

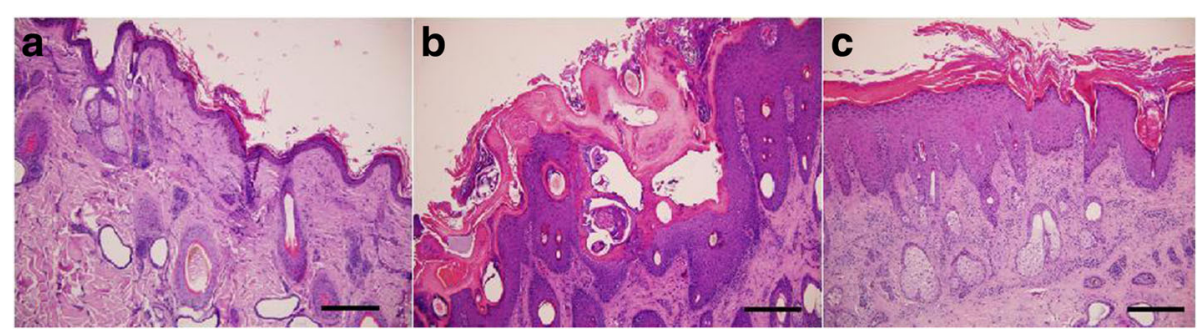

Fig. 2 Light micrographs of ibex skins. a Section of uninfected ibex skin. b Skin section at 46 dpi. Presence of mites, parakeratotic hyperkeratosis, acanthosis, serocellular and eosinophilic crusts and keratinocytes with spongiotic oedema. c Skin section at 150 dpi. Uniform corneal layer with lesser orthokeratotic hyperkeratosis, severe acanthosis and rete ridges and predominance of mononuclear inflammatory infiltrate Scale-bars:251 $\mathrm{mm}$ 
Table 2 Description of necropsy findings in the non-dermal tissue of the Iberian ibex affected by severe sarcoptic mange

\begin{tabular}{|c|c|c|c|}
\hline Organs & $n$ & Gross pathologic examination & Microscopical findings \\
\hline \multirow[t]{4}{*}{ Superficial LN } & 206 & $\begin{array}{l}\text { Lymphadenomegaly (two and } \\
\text { three times the normal size). }\end{array}$ & $\begin{array}{l}\text { Lymphoid hyperplasia with activation of LF, formation of germinal centers and increase } \\
\text { in lympho-plasma cells and macrophages in cords and medullary sinuses (Serous } \\
\text { lymphadenitis) (+++) }\end{array}$ \\
\hline & & Purulent lesion (7.76\%) (Fig. 3) & Purulent lymphadenitis (7.76\%) (+++) \\
\hline & & Edema & Congestion and edema $(+++)$ \\
\hline & & Congestion & Subcapsular, follicular and medullary amyloidosis (71.35\%) (++) \\
\hline \multirow[t]{3}{*}{ Deep LN } & 105 & $\begin{array}{l}\text { Lymphadenomegaly (less than } \\
\text { twice the normal size) }\end{array}$ & Histological pattern similar to superficial LN (++) \\
\hline & & Edema & Subcapsular, follicular and medullary amyloidosis (75.23\%) (++) \\
\hline & & Congestion & Sarcocystis spp. (mesenteric LN) (12.38\%) (+) \\
\hline CNS & 12 & Subdural congestion & Gliosis and perivascular cuffs of mononuclear cell (25.00\%) $(+)$ \\
\hline Tongue & 34 & None & $\begin{array}{l}\text { Sarcocystis spp. with cellular infiltration (lymphocytes, mast cells and eosinophils) } \\
(58.82 \%)(+)\end{array}$ \\
\hline Thyroid gland & 34 & None & None \\
\hline \multirow[t]{2}{*}{ Skeletal muscle } & 34 & None & Sarcocystis spp. with monocuclear infiltration (32.35\%) (+) \\
\hline & & & Mononuclear myositis in the absence of parasites $(14.74 \%)(+)$ \\
\hline \multirow[t]{3}{*}{ Heart } & 34 & Hydropericardium (82.35\%) & Sarcocystis spp. (44.11\%) (+) \\
\hline & & Absence of pericardial fat & $\begin{array}{l}\text { Mononuclear myocarditis (monocytes, lymphocytes and plasma cells) with infiltration of } \\
\text { adipose cells }(23.52 \%)(+)\end{array}$ \\
\hline & & Chicken fat clot (35.29\%) & Muscle mineralization (5.88\%) (+) \\
\hline \multirow[t]{3}{*}{ Lungs } & 102 & $\begin{array}{l}\text { Interstitial emphysema in } \\
\text { apical lobes (41.17\%) }\end{array}$ & $\begin{array}{l}\text { Granulomatous inflammation with presence of intra- alveolar parasites and infiltration of } \\
\text { eosinophils, neutrophils and lymphocytes (verminous pneumonia) }(88.23 \%)(+++)\end{array}$ \\
\hline & & $\begin{array}{l}\text { Fibrotic nodular lesions in } \\
\text { caudal lobes }(88.23 \%)\end{array}$ & $\begin{array}{l}\text { Infiltration of neutrophils, eosinophils, macrophages and lymphocytes, congestion, edema } \\
\text { and areas of necrosis (bacterial pneumonia) }(8.82 \%)(+++)\end{array}$ \\
\hline & & & $\begin{array}{l}\text { Infiltration of neutrophils, eosinophils, macrophages and lymphocytes, congestion, edema } \\
\text { and areas of necrosis (bacterial pneumonia) }(8.82 \%)(+++)\end{array}$ \\
\hline \multirow[t]{2}{*}{ Abdominal cavity } & 34 & Ascitic fluid (transudate) & \\
\hline & & Hepatoperitoneal cysticercosis & \\
\hline \multirow[t]{3}{*}{ Liver } & 34 & Congestion & Perivascular amyloid deposits in portal triad and hepatic sinusoids (11.76\%) (++) \\
\hline & & Increased size & Congestion $(+++)$ and leukocytosis (67.64\%) (++) \\
\hline & & Fibrosis (8.82\%) & Parasitic fibrosis (8.82\%) (+) \\
\hline \multirow[t]{2}{*}{ Kidney } & 68 & Absence of perirenal fat & $\begin{array}{l}\text { Amyloid deposits in glomerular mesangium (amyloid nephrosis) and cortical and medullary } \\
\text { tubular interstitium with decreased capillary lumen (chronic interstitial nephritis and } \\
\text { ischemic tubular atrophy) }(20.58 \%)(++)\end{array}$ \\
\hline & & Congestion & Mesangial thickening, tubular mineralization and leukocytosis (50.00\%) (+) \\
\hline \multirow[t]{2}{*}{ Adrenal gland } & 68 & Increased size & Amyloid deposits in cortex and adrenal medulla $(26.47 \%)(++)$ \\
\hline & & Increased color & Leukocytosis (5.88\%) (+) and adrenal cortical hypoplasia (17.64\%) (+++) \\
\hline \multirow[t]{3}{*}{ Spleen } & 34 & Increased size & Hyperplasia of LF with formation of germinal centers $(+++)$ \\
\hline & & Lymphoid hyperplasia & $\begin{array}{l}\text { Amyloid deposits in LF and PLS of the white pulp and the splenic cords and venous sinuses } \\
\text { of the red pulp "sago spleen" (70.58\%) (+++) }\end{array}$ \\
\hline & & Congestion & Congestion $(+++)$ and leukocytosis (+) \\
\hline Pancreas & 26 & None & Amyloid deposits in exocrine pancreas (15.38\%) $(+)$ and leukocytosis $(+)$ \\
\hline Intestine & 66 & Congestion & $\begin{array}{l}\text { Chronic parasitic enteritis }(21.21 \%)(++) \\
\text { Amyloid deposits in MALT }(25.75 \%)(+)\end{array}$ \\
\hline Testicle & 7 & None & None \\
\hline Ovary & 32 & None & None \\
\hline
\end{tabular}

The table includes the number of samples analyzed $(n)$ and the detection rate (\%). The generalized findings do not show the detection rate. Each change was scored from + to +++ , where $+=$ focal, $++=$ multifocal, $+++=$ generalized

Abbreviations: LN, lymph node; LF, lymphoid follicle; CNS, central nervous system; BALT, bronchus-associated lymphoid tissue; PLS, peri-arteriolar lymphoid sheaths; MALT, mucosa-associated lymphoid tissue 
first 46 dpi. However, except for neutrophils (post-hoc test: $P=0.019$ ), these values showed no significant differences (post-hoc test: $P=0.394$ ) with the ibex that reached the most severe stages of the disease.

Other changes observed (not shown in Table 1) include: mixed hyperkeratosis (ortho-and parakeratotic) with a predominance of the orthokeratotic form 46 $\mathrm{dpi}$, bacterial colonies on the surface, mite feces, dermal fibrosis from the basal lamina to secretory duct of the sebaceous glands, multifocal deposits of melanin at the level of the basal lamina, pilose follicles in the catagen phase, and the dilation of the apocrine glands. Folliculitis was only detected in one ibex.

The histopathological findings in the non-dermal tissues are detailed in Table 2. Samples from experimentally and naturally infested ibex were evaluated together, due to the similar clinical picture of these animals. No differences (Fisher's exact test: $P>0.087$; OR: 0.579; 95\% CI: 0.342-0.975) were found between the lesions observed in the two groups.

\section{Biomarkers of inflammation}

With respect to the healthy group, $\mathrm{AChE}$ concentrations increased significantly (Wilcoxon rank sum test: $W=78$, $P=0.0037$ ) in the ibex with localized lesions (with maximum values at $46 \mathrm{dpi}$ ) and, by contrast, decreased in severely infected animals (Wilcoxon rank sum test: $W=93$, $P=0.015)$ (Table 3 ). AChE values were positively correlated with the number of lymphocytes $\left(r_{(374)}=0.531, P=\right.$ $0.032)$, eosinophils $\left(r_{(388)}=0.343, P=0.042\right)$, mast cells $\left(r_{(363)}=0.398, P=0.0076\right)$ and neutrophils $\left(r_{(452)}=0.252\right.$, $P=0.011)$ found in mangy skin lesions. SAA concentrations only increased significantly (Wilcoxon rank sum test: $W=6.5, P<0.0001)$ in the most severe stages of the disease (Table 3 ). SAA values were negatively correlated $\left(r_{(496)}=-0.184, P=0.0087\right)$ with $\mathrm{AChE}$ concentrations. At the time of euthanasia, serum SAA levels were positively correlated $\left(r_{(282)}=0.719, P<0.0001\right)$ with the number of organs that showed reactive amyloidosis (Table 4).

\section{Microbiology}

The different microbiological agents isolated on mangy skin, lesions and other tissues are shown in Table 5. The evaluation of the accuracy of MALDITOF MS was determined by calculating its sensitivity and specificity for each of the isolated species. The sensitivity and specificity values were 100\% (95\% CI: 40.7-100 and 89.8-100, respectively, depending on the species). All identifications of the isolated agents included in Table 5 are considered to be consistent and reliable, with an average score and range of 2.230 (2.134-2.875) (MALDI Biotyper Real Time Classification software).

\section{Discussion}

The present study reveals structural changes in the skin and several internal organs in Iberian ibex affected by sarcoptic mange, and shows a relationship between pathological findings and the systemic inflammatory response. Additionally, mangy skin and lesions associated with $S$. scabiei infection were characterized microbiologically.

The macroscopic and histological skin lesions observed in mangy ibex closely match the classical descriptions of sarcoptic mange in wild and domestic animals [1, 3]. The cellular response was dominated largely by mononuclear cells, eosinophils and mast cells (intact and degranulated) up to $46 \mathrm{dpi}$. Subsequently, the number of cells fell significantly from 103 dpi onward. Our observations agree with those in red foxes (Vulpes vulpes) [8], raccoon dogs (Nyctereutes procyonoides) [27], wombats (Vombatus ursinus) [28] and Eurasian lynx (Lynx lynx) [29]. However, the infiltration of eosinophils and mast cells was not as intense as in the above mentioned species and was similar to the findings previously described in wild boars [30], which may explain the presence of less obvious marked hyperkeratosis. According to our results, ibex showed signs that are compatible with a combined type I (immediate) and type IV (delayed) hypersensitivity reaction to infection [31]. We thus propose that up to $46 \mathrm{dpi}$, the histological pattern corresponded to type I hypersensitivity since cytotoxicity signs were observed (Fig. 2b) and correlated positively with the number of cells. Subsequently, these signs decreased along withthe cellular infiltrate which suggests type IV hypersensitivity (Fig. 2c).This conclusion needs to be demonstrated by future studies by the immune-histochemical isotype of the lymphocytes or by the expressed cytokine pattern. The neutrophilic response could be due not only to the presence of the mites, but also to secondary bacterial infections or excoriations. As in all other species, the number of plasma cells was low, which may be linked to a reduced role of the humoral response in the infection. We can therefore say that the overexpression of eosinophils, mast cells and

Table 3 Median \pm SD (range) of serum SAA and AChE concentrations in Iberian ibex according their sarcoptic mange status

\begin{tabular}{llll}
\hline & Healthy & Mildlly affected & Severely affected \\
\hline SAA $(\mu \mathrm{g} / \mathrm{ml})$ & $4.45 \pm 6.47^{\mathrm{a}}(1.50-26.80)$ & $4.72 \pm 11.52^{\mathrm{a}}(1.50-51.40)$ & $11.61 \pm 13.47^{\mathrm{b}}(1.51-80.40)$ \\
AChE $\left(\mu \mathrm{mol} / \mathrm{m} l^{*} \mathrm{~min}\right)$ & $0.29 \pm 0.12^{\mathrm{a}}(0.21-0.80)$ & $0.42 \pm 0.19^{\mathrm{b}}(0.20-0.12)$ & $0.33 \pm 0.17^{\mathrm{c}}(0.10-0.90)$ \\
\hline
\end{tabular}

Note: Values that have different superscript letters (a-c) along the row differ significantly 
Table 4 Median \pm SD (range) of serum SAA concentrations in relation to the percentage of amyloidosis detected in the total number of organs analyzed per ibex $(n=25)$

\begin{tabular}{lllll}
\hline & Not detected & $<25 \%$ & $25-50 \%$ & $>50 \%$ \\
\hline SAA $(\boldsymbol{\mu} \mathrm{g} / \mathrm{ml})$ & $5.05 \pm 4.67^{\mathrm{a}}(1.50-9.50)$ & $9.50 \pm 4.61^{\mathrm{b}}(1.51-10.80)$ & $14.35 \pm 7.44^{\mathrm{c}}(9.30-31.30)$ & $21.65 \pm 9.97^{\mathrm{d}}(11.40-51.40)$ \\
\hline
\end{tabular}

Note: Values that have different superscript letters (a-d) along the row differ significantly

neutrophils was associated with a detrimental and non-protective response that was unable to control the infection. This was shown by the observations of ibex with self-limiting clinic process. The presence of abundant serocellular crusts is apparently a mechanism that destroys mites or inhibits their burrowing into the skin as these crusts contain specific antibodies and other toxic components that can intoxicate mites [32]. The hypertrophy and dilation of sebaceous and apocrine glands could be due to the obstruction of the excretory duct of glands by the hyperkeratotic crusts. Finally, the orto- and parakeratotic scales in the stratum corneum correspond to the previous passage of mites through the incompletely differentiated layers of the epidermis.

Cholinesterases have been reported as having the capacity to increase local and systemic inflammatory events in various pathological states [33]. In our study we observed an increase in $\mathrm{AChE}$ levels in the localized form of the disease in experimentally-infested ibex (Table 3), which coincides and correlates significantly with the increase in inflammatory activity observed in the mangy skin during the first $46 \mathrm{dpi}$. Our results are similar to those described in canine demodicosis [34] and reinforce the idea that $S$. scabiei infection alters the cholinergic system and thereby contributing to the establishment of the local inflammatory response and the pathogenesis of the disease.

The most prominent histological findings in nondermal tissues were lymphoid hyperplasia, leukocytosis, congestion, and the presence of amyloid deposits (Table 2). Systemic amyloidosis often occurs secondarily to chronic inflammatory or necrosis as is the case of sarcoptic mange [11,35]. Serum SAA is an acute phase protein of inflammation [36]. In our study, serum SAA concentrations increased significantly in the

Table 5 Microbiological agents isolated by the MALDI-TOF MS method in Iberian ibex $(n=34)$ affected by severe sarcoptic mange

\begin{tabular}{|c|c|c|c|c|c|}
\hline \multicolumn{2}{|l|}{ Mangy skin $(n=34)$} & \multicolumn{2}{|c|}{ Superficial suppurative lesions $(n=16)^{a}$} & \multicolumn{2}{|l|}{ Other tissues $(n=43)$} \\
\hline Agent & $\%$ & Agent & $\%$ & Agent & $\%$ \\
\hline Bacillus altitudinis & 5.88 & Aerococcus viridians & 6.25 & Lungs $(n=12)$ & \\
\hline Corynebacterium glutamicum ${ }^{c}$ & 2.94 & Corynebacterium glutamicum ${ }^{c}$ & 6.25 & Pasteurella multocida & 25.00 \\
\hline Escherichia coli & 14.70 & Staphylococcus aureus & 43.75 & Staphylococcus aureus & 25.00 \\
\hline Proteus vulgaris & 11.76 & Staphylococcus warneri & 25.00 & Staphylococcus sciuri & 8.33 \\
\hline Pseudomonas aeruginosa & 17.64 & Staphylococcus simulans & 7.69 & Staphylococcus warneri & 25.00 \\
\hline Staphylococcus aureus & 52.92 & Staphylococcus xylosus & 7.69 & Streptococcus lutitiensis & 16.66 \\
\hline Staphylococcus warneri & 29.41 & Staphylococcus nepalensis ${ }^{\mathrm{b}}$ & 6.25 & Liver $(n=11)$ & \\
\hline Staphylococcus sciuri & 8.82 & Streptococcus ovis & 18.75 & Staphylococcus aureus & 36.36 \\
\hline Staphylococcus simulans & 5.88 & Trueperella pyogenes & 25.00 & Staphylococcus xylosus & 18.18 \\
\hline Staphylococcus chromogenes & 2.94 & & & Streptococcus lutitiensis & 27.27 \\
\hline Staphylococcus xylosus & 5.88 & & & Spleen $(n=10)$ & \\
\hline Staphylococcus nepalensis ${ }^{\mathrm{b}}$ & 5.88 & & & Escherichia coli & 20.00 \\
\hline Streptococcus pluranimalium & 2.94 & & & Staphylococcus aureus & 30.00 \\
\hline \multirow[t]{6}{*}{ Streptococcus lutitiensis } & 5.88 & & & Streptococcus warneri & 20.00 \\
\hline & & & & Kidney $(n=10)$ & \\
\hline & & & & Escherichia coli & 20.00 \\
\hline & & & & Staphylococcus aureus & 40.00 \\
\hline & & & & Staphylococcus xylosus & 20.00 \\
\hline & & & & Streptococcus lutitiensis & 20.00 \\
\hline
\end{tabular}

The table includes the number of samples analyzed ( $n$ ) and detection rate (\%)

${ }^{\text {a }}$ Suppurative lesions detected in superficial lymph nodes and subcutaneous tissue

b Isolated only in naturally infected ibex

'Isolated only in experimentally infected ibex 
most severe phase of the disease (Table 3), which coincides with the description by Ráez-Bravo [37]. In addition, higher levels were present in ibex in which more tissues with amyloidosis were detected (Table 4). This is because increased levels of this protein lead to a precipitation of its insoluble forms and turn it into a pathological protein [38]. A secondary effect of amyloid deposits could be the atrophy and necrosis of juxtaposed cells due to pressure (Fig. 3). Such lesions could be involved with changes in the serology and blood chemistry reported in mangy ibex [17]. Additionally, leukocytosis could be attributable to the cellular immune response, tissue response to damage or necrosis caused by inflammation or septicaemia. Generalized lymphadenomegaly, together with lymphoid hyperplasia, are congruent with a cellmediated immune response [3], although it could also be related to secondary infections of the damaged skin. Among the gross findings, transudate fluid was found in the pericardium and the abdominal cavity. This may have been caused by hypoproteinemia associated with disease [17], or by liver or kidney lesions derived from amyloidosis. Finally, pericardial effusion could trigger restrictive cardiac insufficiency that could explain the generalized congestion that was noted, as well as the weakness and prostration described in some ibex.
A wide variety of bacterial agents were isolated in mangy ibex (Table 5). The simultaneous presence of these pathogens in mangy skin, and also suppurative lesions in lymph nodes and in various organs is compatible with a septicaemic pattern of infection [12, 39]. The bacteria identified were similar to those previously described in psoroptic mange and other skin diseases in livestock [40, 41]. Staphylococcus was the dominant genus and infrequent species such as S. nepalensis were isolated. Infections by these bacteria are often secondary to a primary skin disease that provides the conditions for these commensal bacteria to proliferate $[40,42,43]$. Under these conditions, some bacterial strains can produce diverse dermotoxins that can aggravate the skin injuries produced by mites [44, 45]. Further toxicity studies are necessary if we are to specify the type of toxins expressed in mangy ibex. It has also been demonstrated that the colonization of skin lesions due to Psoroptes ovis with $S$. aureus causes a specific response of IgG antibodies against $S$. aureus antigens, suggesting that these bacteria may play some role in the immunepathogenesis of mange [46]. The mites themselves could contribute to the spread of these pathogenic bacteria since various strains of Staphylococcus have been isolated in mite burrows and in their faecal pellets [47]. However, it has been reported that both mites and the

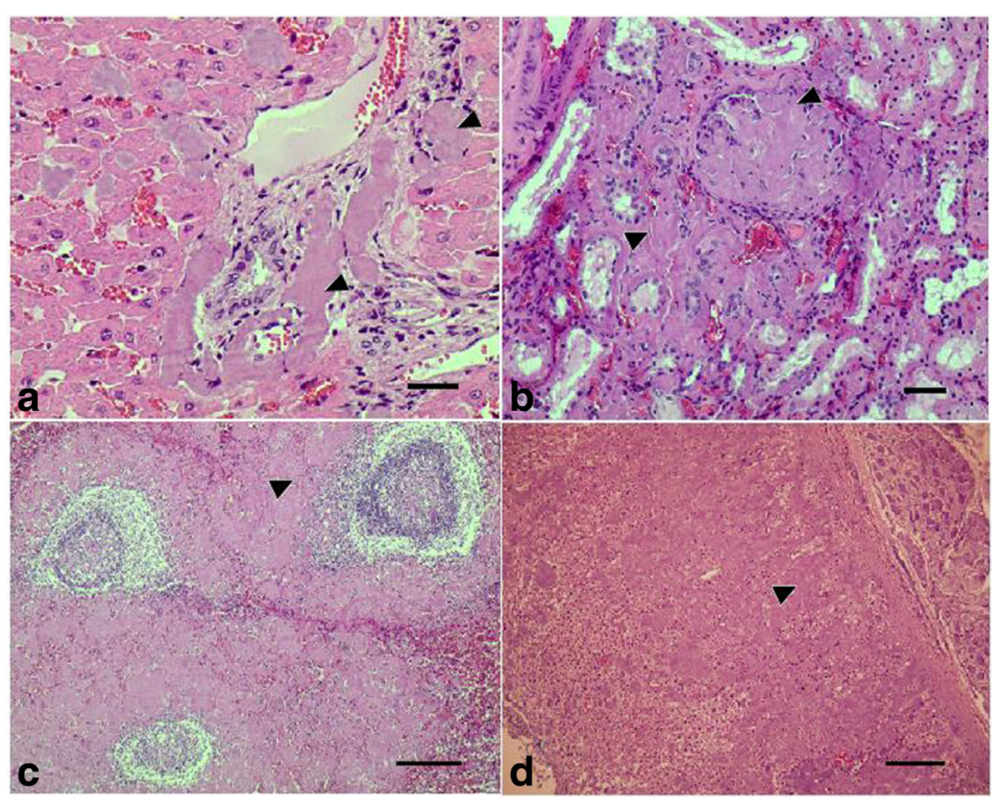

Fig. 3 Light micrographs of ibex non-dermal organs. a Liver. Perivascular amyloid deposits in portal spaces and hepatic sinusoids (arrowheads) and congestion. $\mathbf{b}$ Kidney. Loss of glomerular structure due to the presence of amyloid deposits (arrowheads) at the mesangial level with a reduction of urinary spaces (amyloid nephrosis) and at the level of cortical tubular interstitium with decreased capillary lumens (chronic interstitial nephritis and ischemic tubular atrophy). c Spleen. Amyloid deposits (arrowhead) at the level of the mantle and crown of the Malpigian follicles and peri-arteriolar lymphoid sheaths of the white pulp, extending to splenic cords and venous sinuses of the red pulp ("Sago spleen").d Adrenal gland. Loss of adrenal structure due to the presence of amyloid deposits (arrowhead) at the glomerular and fascicular levels of the adrenal cortex. Scale-bars: $\mathbf{a}, 62.7 \mu \mathrm{m} ; \mathbf{b}, 62.7 \mu \mathrm{m} ; \mathbf{c}, 251 \mu \mathrm{m} ; \mathbf{d}, 251 \mu \mathrm{m}$ 
skin bacteria produce molecules that inhibit the pathways of the complement system and stimulate the production of various cytokines and, thereby, promoting bacterial survival and growth as well as the chemotaxis of inflammatory cells $[13,48]$.

In humans, especially in children, scabies-associated skin bacterial infection is a common risk factor for systemic complications such as acute post-streptococcal glomerulonephritis and sometimes rheumatic heart disease $[49,50]$. However, in mangy ibex, no necrotic foci, abscesses or signs of inflammation associated with bacteremia were found in the kidneys, livers, spleens or lungs. This thereby indicates that the lympho-hematogenus dissemination of these pathogens a priori has fewer serious consequences than in other species [11, 12, 29, 39]. The areas of myocarditis and gliosis detected have also been described in other species with sarcoptic mange [29, 39], although in our case we cannot assume that this was due to the septicaemic state. From a veterinary perspective, the administration of antibiotic substances should be considered, in addition to antiparasitic treatment, in the individual treatment of sarcoptic mange in the Iberian ibex.

\section{Conclusion}

In this study we provide a complete description of sarcoptic mange in the Iberian ibex through a description of its effects in naturally and experimentally infested animals, combining a serological, microbiological and histological approach. The alteration of biomarkers of inflammation and its implication in the pathogenesis of the disease and development of lesions in non-dermal tissues and septicaemic processes are serious conditioners for the survival of mangy ibex. These findings could be relevant in the management of affected ibex populations, since this could contribute to decisions on the elimination of animals that exceed a certain disease threshold from a population. In turn, our work provides a solid basis for further investigation of other factors that influence the pathogenesis of this disease.

\section{Acknowledgements}

We would like to thank the Consejería de Medio Ambiente de la Junta de Andalucía and in particular the Sierra Nevada Natural Space (SNNS) for their logistical support and to the Sierra de Huétor Natural Park for the transfer of their experimental facilities. Special thanks are also due to the park wardens and fieldworkers in the SNNS, and above all to Apolo Sánchez, José López, Isidro Puga, Elías Martínez, Francisco Felipe and Antonio Rodríguez for their professional and personal involvement in the study. We are also grateful Manolo Herrera for the maintenance of the ibex and the facilities during the experimental phase and the contributions of the SCSVNP to the study. Thank you to Michael Lockwood for the English revision, to the Health Surveillance VISAVET Centre of the Complutense University of Madrid and Department of Microbiology at the University of Jaén for the microbiological diagnosis, the Interdisciplinary Laboratory of Clinical Analysis (Interlab-UMU) of the University of Murcia for the serum assays, and the Service of Veterinary Pathology of the UAB for the histological preparation of samples.

\section{Funding}

This study was funded by MINECO from the Spanish Government (grant numbers CGL2012-40043-C0-01, CGL2012-40043-CO2-02 and CGL201680543-P). The authors' research activities are partially funded by the PAIDI Research Group RNM-118 from Junta de Andalucia. José Espinosa was supported by a PhD Grant (grant number ECC/1402/2013: BES-2013-063931).

This study is part of the project "Bases biológicas para la gestión de la sarna sarcóptica en la cabra montés (Capra pyrenaica) de Sierra Nevada".

\section{Availability of data and materials}

Data supporting the conclusions of this article are included within the article.

\section{Authors' contributions}

Designed the study: JE, RV, JMP and JLO. Performed the ibex sampling: JEG, JLO, FJCM, PF, JE, AR and RCS. Laboratory analyses: AT, DR, RV, SL and JE. Analyzed the data: JE, JMP, RV and RCS. Wrote the paper: JE. All authors read and approved the final manuscript.

\section{Ethics approval}

This study complied with all Andalusian, Spanish and European legal requirements and guidelines regarding experimentation and animal welfare. Handling procedures and sampling frequency were designed to reduce stress and minimize the impact on the health of the subjects, as per European (2010/63/UE) and Spanish (R.D 53/2013) standards. The study was approved by the Ethics on Animal Welfare Committee of the University of Jaén and authorized by the Dirección General de Producción Agrícola y Ganadera of the Consejería de Agricultura, Pesca y Medio Ambiente of the Junta de Andalucía (Ref: SA/SIS/MD/ps/ October 25, 2012). The Sierra Nevada Natural Park staff also approved this study.

Consent for publication

Not applicable.

\section{Competing interests}

The authors declare that they have no competing interests.

\section{Publisher's Note}

Springer Nature remains neutral with regard to jurisdictional claims in published maps and institutional affiliations.

\section{Author details}

${ }^{1}$ Departamento de Biología Animal, Vegetal y Ecología, Universidad de Jaén, Campus Las Lagunillas s/n, 23071 Jaén, Spain. ${ }^{2}$ Servei d'Ecopatologia de Fauna Salvatge (SEFaS), Departament de Medicina i Cirurgia Animals, Universitat Autònoma de Barcelona (UAB), E-08193 Bellaterra, Barcelona, Spain. ${ }^{3}$ Departament de Medicina i Cirugia Animals, Universitat Autònoma de Barcelona (UAB), E-08193, Bellaterra, Barcelona, Spain. ${ }^{4}$ Espacio Natural Sierra Nevada, Carretera Antigua de Sierra Nevada, Km 7, E-18071 Pinos Genil, Granada, Spain. ${ }^{5}$ Agencia de Medio Ambiente y Agua, Isla de la Cartuja, E-41092 Sevilla, Spain. ${ }^{6}$ Estación Biológica de Doñana (CSIC), Av. Américo Vespucio, s.n, E-41092 Sevilla, Spain. ${ }^{7}$ Área de Toxicología, Facultad de Veterinaria, Universidad de Murcia, 30100 Murcia, Spain.

Received: 11 August 2017 Accepted: 20 November 2017

Published online: 04 December 2017

\section{References}

1. Pence DB, Ueckermann E. Sarcoptic mange in wildlife. Rev Sci Tech. 2002; 21:385-98.

2. Fernández-Morán J, Gómez S, Ballesteros F, Quirós P, Benito JL, Feliu C, Nieto JM. Epizootiology of sarcoptic mange in a population of Cantabrian chamois (Rupicapra pyrenaica parva) in northwestern Spain. Vet Parasitol. 1997:73:163-71.

3. Bornstein S, Morner T, Samuel WM. Sarcoptes scabiei and sarcoptic mange. In: Samuel WM, Pybus MJ, Kocan AA, editors. Parasitic diseases of wild mammals, 2nd ed. London, UK: Manson Publishing; 2001, pp. 107-119.

4. Soulsbury CD, lossa G, Baker PJ, Cole NC, Funk SM, Harris S. The impact of sarcoptic mange Sarcoptes scabiei on the British fox Vulpes vulpes population. Mammal Rev. 2007;37:278-96.

5. Fandos P. La cabra montés (Capra pyrenaica) en el Parque Natural de las Sierras de Cazorla, Segura y Las Villas. Madrid: ICONA-CSIC; 1991. p. 176. 
6. Pérez JM, Ruiz-Martínez I, Granados JE, Soriguer RC, Fandos P. The dynamics of sarcoptic mange in the ibex population of sierra Nevada in Spain influence of climatic factors. J Wildl Res. 1997;2:86-9.

7. Walton SF, Currie BJ. Problems in diagnosing scabies, a global disease in human and animal populations. Clin Microbiol Rev. 2007;20:268-79.

8. Nimmervoll H, Hoby S, Robert N, Lommano E, Welle M, Ryser-Degiorgis MP. Pathology of sarcoptic mange in red foxes (Vulpes vulpes): macroscopic and histologic characterization of three disease stages. J Wildl Dis. 2013;49:91-102.

9. Newman TJ, Baker PJ, Harris S. Nutritional condition and survival of red foxes with sarcoptic mange. Vet Dermatol. 2002;80:154-61.

10. Carvalho J, Granados JE, López-Olvera JR, Cano-Manuel FJ, Pérez JM, Fandos P, et al. Sarcoptic mange breaks up bottom-up regulation of body condition in a large herbivore population. Parasit Vectors. 2015;8:572.

11. Arlian LG, Bruner RH, Stuhlman RA, Ahmed M, Vyszenski-Moher DL. Histopathology in hosts parasitized by Sarcoptes scabiei. J Parasitol. 1990;76: 889-94

12. Nakagawa TL, Takai Y, Kubo M, Sakai H, Masegi T, Yanai TA. Pathological study of sepsis associated with sarcoptic mange in raccoon dogs (Nyctereutes procyonoides) in Japan. J Comp Pathol. 2009;141:177-81.

13. Swe PM, Zakrzewski M, Kelly A, Krause L, Fischer K. Scabies mites alter the skin microbiome and promote growth of opportunistic pathogens in a porcine model. PLoS Negl Trop Dis. 2014;8:e2897.

14. León-Vizcaíno L, Ruíz de Ybánez MR, Cubero MJ, Ortíz JM, Espinosa J, Pérez L, et al. Sarcoptic mange in Spanish ibex from Spain. J Wild Dis. 1999:35:647-59.

15. Serrano E, Granados JE, Pérez JM. Sarcoptic mange and metapodial development in growing male Iberian ibex (Capra pyrenaica). Vet Parasitol. 2007;144:375-9.

16. Sarasa M, Serrano E, Soriguer RC, Granados JE, Fandos P, Gonzalez G, et al. Negative effect of the arthropod parasite, Sarcoptes scabiei, on testes mass in Iberian ibex, Capra pyrenaica. Vet Parasitol. 2011;175:306-12.

17. Pérez JM, Serrano E, Soriguer RC, González FJ, Sarasa M, Granados JE, et al. Distinguishing disease effects from environmental effects in a mountain ungulate: seasonal variation in body weight, hematology and serum chemistry among Iberian ibex (Capra pyrenaica) affected by sarcoptic mange. J Wild Dis. 2015;51:148-56.

18. Ráez-Bravo A, Granados JE, Serrano E, Dellamaria D, Casais R, Rossi L, et al. Evaluation of three enzyme-linked immunosorbent assays for sarcoptic mange diagnosis and assessment in the Iberian ibex, Capra pyrenaica. Parasit Vectors. 2016;9:558.

19. Europe. Directiva 2010/63/UE, de 22 de septiembre de 2010, relativa a la protección de los animales utilizados para fines científicos. DOUE. 2010;276: 33-79.

20. España. Real Decreto 53/2013, de 1 de Febrero, por el que se establecen las normas básicas aplicables para la protección de los animales utilizados en experimentación y otros fines científicos, incluyendo la docencia. BOE. 2013; 34:11370-421

21. Casas-Díaz E, López-Olvera JR, Marco I, Mentaberre G, Lavin S. Hematologic and biochemical values for Spanish ibex (Capra pyrenaica) captured via drive-net and box-trap. J Wild Dis. 2008:44:965-72.

22. Pérez JM, Granados JE, Sarasa M, Serrano E. Usefulness of estimated surface area of damaged skin as a proxy of mite load in the monitoring of sarcoptic mange in free-ranging populations of Iberian wild goat, Capra pyrenaica. Vet Parasitol. 2011;176:258-64.

23. Sarasa M, Rambozzi L, Rossi L, Meneguz PG, Serrano E, Granados JE, et al. Sarcoptes scabiei: specific immune response to sarcoptic mange in the Iberian ibex Capra pyrenaica depends on previous exposure and sex. Exp Parasitol. 2010;124:265-71.

24. Ellman GL, Courtney KO, Andres V, Feather-Stone RMA. New and rapid colorimetric determination of acetylcholinesterase activity. Biochem Pharmacol. 1961;7:88-95.

25. Tecles F, Martinez-Subiela S, Bernal LJ, Cerón JJ. Use of whole blood for spectrophotometric determination of cholinesterase activity in dogs. Vet J. 2000;160:242-9.

26. R Development Core Team. R: A Language and Environment for statistical computing. (Vienna, R Foundation for Statistical Computing); 2016, https://www.r-project.org.

27. Ninomiya $H$, Ogata M. Sarcoptic mange in free-ranging raccoon dogs (Nyctereutes procyonoides) in Japan. Vet Dermatol. 2005;16:177-82.

28. Skerratt LF. Clinical response of captivity common wombats (Vombatus ursinus) infected with Sarcoptes scabiei var. wombati. J Wildl Dis. 2003; 39:179-92.
29. Ryser-Degiorgis MP, Ryser A, Bacciarini LN, Angst C, Gottstein B, Janovsky M, Breitenmoser $U$. Notoedric and sarcoptic mange in free-ranging lynx from Switzerland. J Wildl Dis. 2002;38:228-32.

30. Haas C, Origgi FC, Akdesir E, Batista Linhares M, Giovannini S, Mavrot F, et al. First detection of sarcoptic mange in free-ranging wild boar (Sus scrofa) in Switzerland. Schweiz Arch Tierheilkd. 2015;157:269-75.

31. Lalli PN, Morgan MS, Arlian LG. Skewed Th1/Th2 immune response to Sarcoptes scabiei. J Parasitol. 2004;90:711-4.

32. Tarigan S. Histopathological changes in naïve and sensitised goats caused by Sarcoptes scabiei infestation. JITV. 2003;8:114-21.

33. Das UN. Acetylcholinesterase and butyrylcholinesterase as possible markers of low-grade systemic inflammation. Med Sci Monit. 2007;13:214-21.

34. Martínez-Subiela S, Bernal LJ, Tvarijonaviciute A, Garcia-Martinez JD, Tecles F, Cerón JJ. Canine demodicosis: the relationship between response to treatment of generalized disease and markers for inflammation and oxidative status. Vet Dermatol. 2014;72-76:23-4.

35. Casais $R$, Dalton KP, Millán J, Balseiro A, Oleaga A, Solano $P$, et al. Primary and secondary experimental infestation of rabbits (Oryctolagus cuniculus) with Sarcoptes scabiei from a wild rabbit: factors determining resistance to reinfestation. Vet Parasitol. 2014;203:173-83.

36. Ceciliani F, Ceron JJ, Eckersall PD, Sauerwein H. Acute phase proteins in ruminants. J Proteomic. 2012;75:4207-31.

37. Ráez-Bravo A, Granados JE, Cerón JJ, Cano-Manuel FJ, Fandos P, Pérez JM, et al. Acute phase proteins increase with sarcoptic mange status and severity in Iberian ibex (Capra pyrenaica, Schinz 1838). Parasitol Res. 2015;114:400510.

38. Cray C, Zaias J, Altman NH. Acute phase response in animals: a review. Comp Med. 2009;59:517-26.

39. Skerratt IF, Middleton D, Beveridge I. Distribution of life cycle stages of Sarcoptes scabiei var wombati and effects of severe mange on common wombats in Victoria. J Wildl Dis. 1999;35:633-46.

40. Foster AP. Staphylococcal skin disease in livestock. Vet Dermatol. 2012;23: 342-51.

41. Hall SA, Mack K, Blackwell A, Evans KA. Identification and disruption of bacteria associated with sheep scab mites-novel means of control? Exp Parasitol. 2015;157:110-6.

42. Bates P. Bacterial associations with the sheep scab mite (Psoroptes ovis). Vet Rec. 2003;152:206-8.

43. Smith MC, Sherman D. Skin. In: Ames, IA, editor. Goat Medicine, 2nd edn. Wiley-Blackwell; 2009; pp. 23-60.

44. Nishifuji K, Sugai M, Amagai M. Staphylococcal exfoliative toxins: "molecular scissors" of bacteria that attack the cutaneous defense barrier in mammals. $J$ Dermatol Sci. 2008;49:21-31.

45. Bukowski M, Wladyka B, Dubin G. Exfoliative toxins of Staphylococcus aureus. Toxins (Basel). 2010;2:1148-65.

46. Oliveira AM, MacKellar A, Hume L, Huntley JF, Thoday KL, van den Broek AH. Immune responses to Staphylococcus aureus and Psoroptes ovis in sheep infected with P. ovis - the sheep scab mite. Vet Immunol Immunopath. 2006;113:64-72.

47. McCarthy JS, Kemp DJ, Walton SF, Currie BJ. Scabies: more than just an irritation. Postgrad Med J. 2004;80:382-7.

48. Swe PM, Fischer KA. Scabies mite serpin interferes with complementmediated neutrophil functions and promotes staphylococcal growth. PLoS Negl Trop Dis. 2014;8:e2928.

49. Ferng SH, Shieh SD, Huang HW, Fan CD, Ho YS, Tu YC. [Scabies associated with secondary streptococcal infection and acute glomerulonephritis.] Taiwan Yi Xue Hui Za Zhi 1982:81:1595-1598. (In Chinese).

50. Parks T, Smeesters PR, Steer AC. Streptococcal skin infection and rheumatic heart disease. Curr Opin Infect Dis. 2012;25:145-53. 